\title{
Tensile Strength of Bamboo After Preservation
}

\author{
Noverma*, Oktavi Elok Hapsari, Yusrianti \\ Faculty of Science and Technology, UIN Sunan Ampel, Jl. Ahmad Yani No 117 Yogyakarta, \\ Email*: noverma@uinsby.ac.id
}

\begin{abstract}
Bamboo has high tensile strength, so it can be an alternative to substitute wood or steel. Bamboo is a material that comes from nature, so it is vulnerable to degraded by weather changes and infected by termites and fungi. The effort to overcome this problem is by preserving before using it. This study aims to determine the tensile strength test results of bamboo after preserving and then compare with the tensile strength test results of bamboo without preserving. The research method was carried out by preserving bamboo by soaking the test sample in a container filled with water for a duration of time; 1 x 24 hours; 3 x 24 hours and 14 x 24 hours. The water used in freshwater with a salinity of $00 / 00$ measured using a salinometer. The results showed that the tensile strength of bamboo increased compared without preserved with a percentage of $12.50 \% ; 23.12 \%$ and $10.59 \%$ for the duration of time respectively $1 \times 24$ hours; $3 \times 24$ hours and 14x24 hours. Optimal tensile strength is obtained at a time duration of 3 x 24 hours and decreases at a longer time duration of $14 \times 24$ hours.
\end{abstract}

Keywords: Bamboo preservation, duration of preservation, the tensile strength of bambo, the weakness of bamboo

\section{INTRODUCTION}

Since ancient times, bamboo has been known and used by the people. Bamboo is used for various crafts, furniture, weapons/ weapons and is also used in arts and culture, besides that bamboo also reduces the risk of disasters such as earthquakes, floods, and drought (Noverma 2017; Noverma et al. 2018). Because bamboo is a natural material that has similar properties to wood, bamboo is vulnerable to degradation by the surrounding environment. Bamboo also has a low resistance to the biotic environment such as powder beetles, termites, insects, or fungi (Jasni et al., 2017). Efforts to overcome the low durability of bamboo, it is essential to preserve bamboo before using it. There are many methods of preserving bamboo, either by simple means without chemicals or by adding chemicals (Chen et al. n.d.; Daud et al. 2018; Gauss et al. 2019; Industri and 2017 n.d.). Bamboo preservation in a simple way can be done by soaking bamboo in water for a certain duration or boiling it. This activity produces a biological process, which can cause fermentation of starch content in bamboo so that fermentation results become soluble in water. Thus, the starch in bamboo decreases and the endurance of bamboo increases. In addition, based on previous research, bamboo has quite good mechanical properties with very high tensile strength and the results of comparison with steel materials show that the tensile strength of bamboo exceeds the tensile strength of steel, so that bamboo can compete (Morisco 2006). Several studies to improve the durability and strength of bamboo have been carried out by previous researchers (Chen et al. n.d.; Daud et al. 2018; Gauss et al., 2019; Industri and 2017 n.d.; Lath and Shukla 2019; Möller and Mild 2019; Uslinawaty et al. 2019). The purpose of this research was to determine the tensile strength of bamboo after preserving and compared with before preserving.

\section{MATERIALS AND METHODS}

\section{Materials}

Test object preparation and testing methods are carried out based on international standards (ISO 22156-1 2004; ISO 22157-1 2004; ISO 22157-2 n.d.). Preservation of specimens is done by soaking in water with salinity 0 $0 / 00$ and at a duration of $1 \times 24$ hours, $3 \times 24$ hours and $14 \times 24$ hours. The specimen uses a type of Bambusa arundinacea that comes from the Mojokerto region of East Java and logging is carried out in the dry season in August. The part of bamboo used is the middle part (internode) that has the same diameter The shape of the specimens is shown in Figure 1.

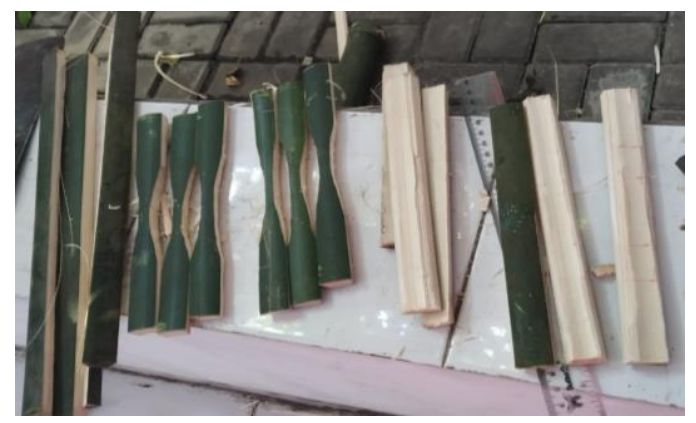

Figure 1. Specimens.

Specimens testing used Universal Testing Machine (UTM). The test machine is equipped with 1 computer unit to facilitate input data of the property of the specimen and provide a stress-strain output diagram 
through printouts. The process of testing the tensile strength of bamboo is shown in Figure 2.

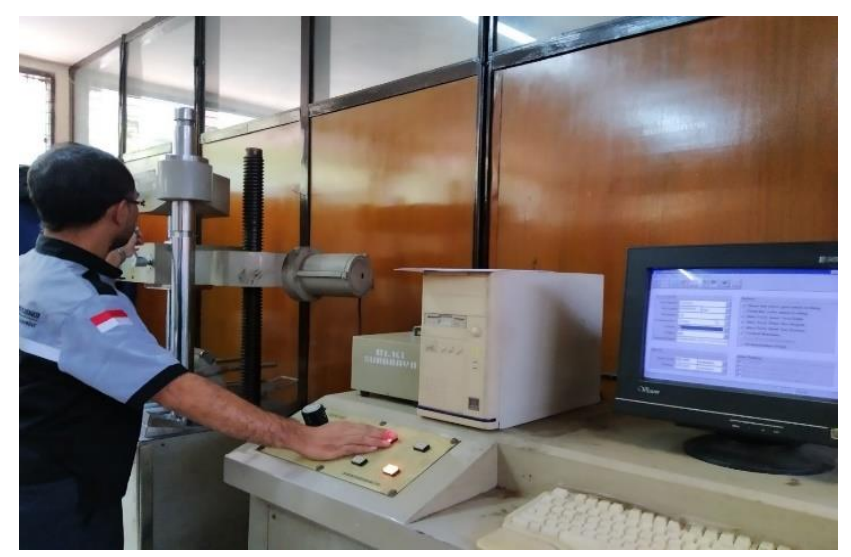

Figure 2. Bamboo tensile strength testing process.

\section{Procedures}

This research was carried out in several steps, which were divided into preparation, implementation, and final steps. The initial step is the step to find the latest problem/problem, so research becomes important. including the purpose, benefits, and methods used in this research. The implementation step of this research is the step of specimen preparation and testing. The Final Step is the step to answer the research purpose which are the activities of making the final research report containing the results, discussion, and conclusions of the research.

\section{RESULTS AND DISCUSSION}

\section{Bamboo tensile test results}

The results of tensile testing of bamboo without preserved and with preserved are shown in Figure 3. The code used on the specimen is $\mathrm{T}$ (without preserved) and AT (with preserved). Based on Figure 3 it is known that the tensile strength of bamboo is almost comparable to the tensile strength of steel (240 MPa) used in the market as concrete reinforcement (Morisco, 2006).

\section{Effect of preserved bamboo on tensile strength}

In this research the treatments were carried out for $1 \times 24$ hour; $3 \times 24$ hours; and $14 \times 24$ hours. Each specimen is given a code, AT1 code for preservation 1x24 hours; AT2 code for preservation $3 \times 24$ hours and AT3 code for preservation $14 \times 24$ hours. The effect of preservation duration is shown in Figure 4.

The results displayed are related to the preservation effect based on the duration of preservation. Specimens preserved for $3 \times 24$ hours provide the highest tensile strength compared to preservation at shorter and longer durations. Based on Figure 4, it is known that the tensile strength of specimens preserved for $3 \times 24$ hours increased by a percentage of $9.46 \%$ compared to specimens preserved for $1 \times 24$ hours. However, the tensile strength decreased by $1.54 \%$ in a longer duration of time $14 \times 24$ hours compared to specimens stored for $1 \times 24$ hours. This is allegedly due to the reduced content of starch in bamboo which functions to bind bamboo fibers (Fattah and Ardhyananta, 2013).

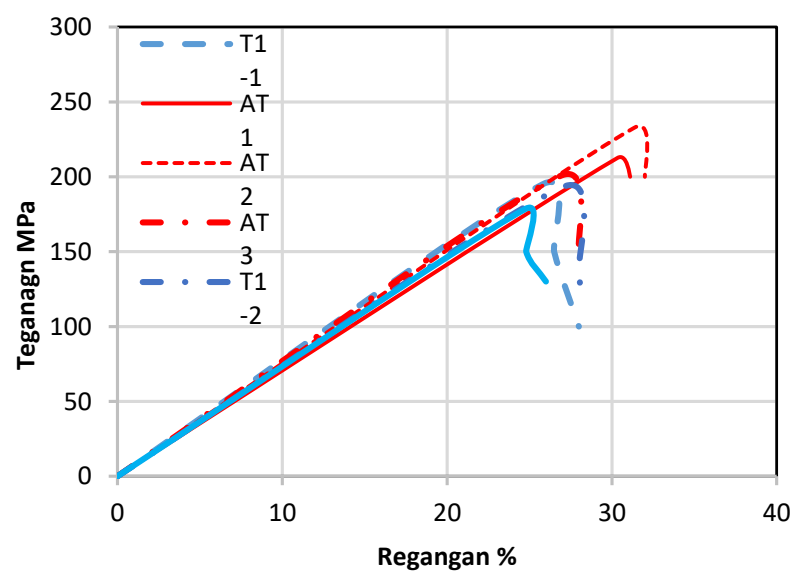

Figure 3. Tensile Strength of Bamboo without and with preservation.

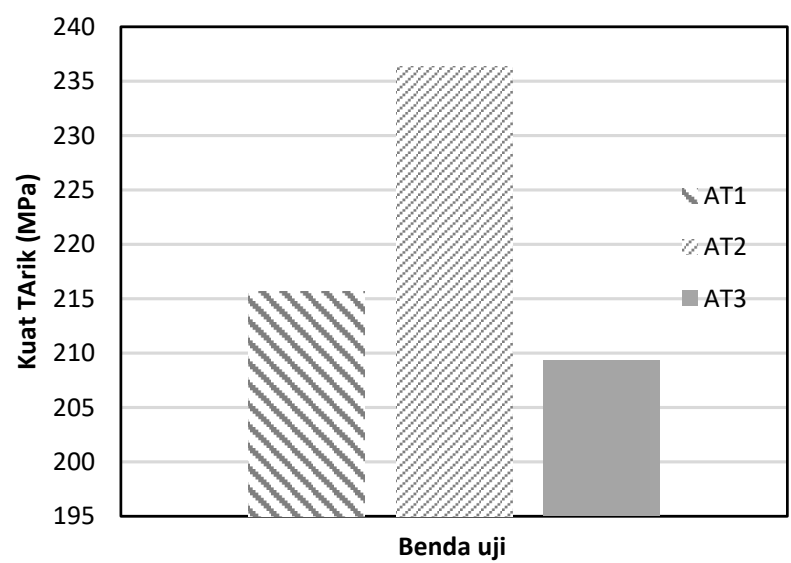

Figure 4. Effect of Bamboo Preservation on Tensile Strength.

\section{The Effect of bamboo which is preserved and without preserves on tensile strength}

Tensile strength of bamboo without preserves and preserved, shown in figure 5. Based on Figure 5, the tensile strength values are varied. This is due to the influence of the duration of preservation and treatment are done at specimens. Specimens without preserves give the lowest tensile strength values compared to preserved ones. Tensile strength increased in specimens with a duration of $3 \times 24$ hours and decreased in the longer preservation duration of $14 \times 24$ hours.

The percentage increase in tensile strength of specimens preserved for $1 \times 24$ hours increased by $12.50 \%$ and increased by $23.12 \%$ in the duration of time $3 \times 24$ hours and increased $10.59 \%$ in the duration of time $14 \times 24$ hours. This is thought to be caused by a longer preservation period, which can break down more starch, 
so the longer the preservation is carried out makes the optimal preservation process but otherwise can reduce its strength.

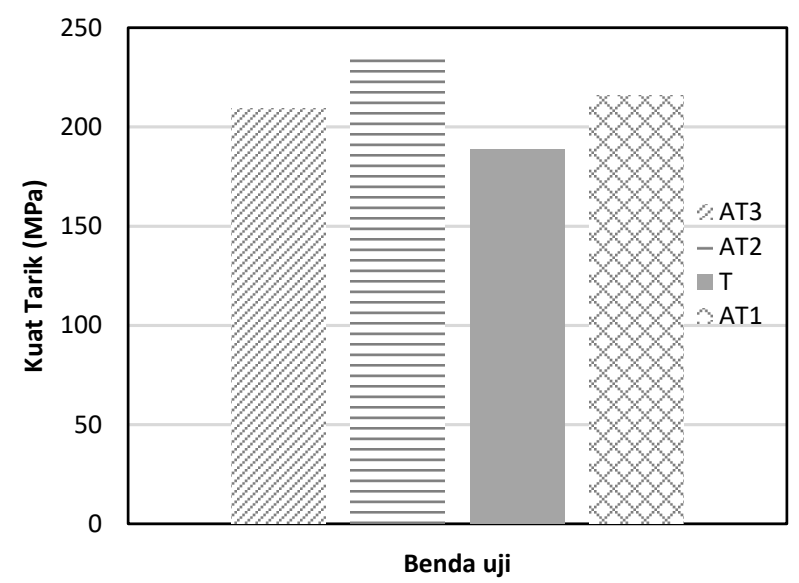

Figure 5. Tensile strength of bamboo preserved and without preserved.

\section{CONCLUSIONS}

Bamboo is preserved at a certain time duration can increase the tensile strength of bamboo. Based on this study, the optimal tensile strength of preserved bamboo increased by $23.12 \%$ in the duration of $3 \times 24$ hours and decreased in preserving with a longer duration of time.

\section{ACKNOWLEDGEMENTS}

Acknowledgments are expressed to all those who have helped in carrying out this research. This research was funded by the 2019 DIPA budget of UIN Sunan Ampel Surabaya.

\section{REFERENCES}

Chen Lin, et al. The Effect of Chemical Treatment on Green Color Preservation and Surface Characteristics of Neosinocalamus Affinis Bamboo.

Daud M.. 2018. Ketahanan dari Serangan Rayap Tanah dari Bambu yang Diawetkan dengan Boron dengan Metode
Modifyed Boucheri (Moburi ). The Development, and The Potency.

Fattah AR, Ardhyananta H. 2013. Pengaruh Bahan Kimia dan Waktu Perendaman Terhadap Kekuatan Tarik Bambu Betung (Dendrocalamus asper) Sebagai Perlakuan Pengawetan Kimia. Jurnal Teknik Pomits 1(1): 1-6.

Gauss, Christian, Kadivar M, Savastano H. 2019. Effect of Disodium Octaborate Tetrahydrate on the Mechanical Properties of Dendrocalamus Asper Bamboo Treated by Vacuum/Pressure Method. Journal of Wood Science 65(1).

Industri, B Pojoh. 2017. Pengaruh Perendaman dalam Air Sungai dan Air Laut Terhadap Daya Tahan Tulangan Bambu Petung Asal Tomohon. Jurnal Penelitian Teknologi, and undefined. https://www.neliti.com/publications/285997/pengaruhperendaman-dalam-air-sungai-dan-air-laut-terhadapdayatahan-tulangan-b (7 November 2019).

ISO 22156-1. 2004. Bamboo- Structural Design.

ISO 22157-1. 2004. Bamboo - Determination of Physical and Mechanical Properties: Part 1, Requirements.

ISO 22157-2. Bamboo - Determination of Physical and Mechanical Properties, Part 2, Laboratory Manual." 2004.

Jasni, Damayanti R, Sulastiningsih IM. 2017. Pengklasifikasian Ketahanan 20 Jenis Bambu Terhadap Rayap Kayu Kering. Jurnal Penelitian Hasil Hutan 35(3): 171-83.

Lath SNK, Shukla A. 2019. Performance Evaluation of Chemically Treated Bamboo Reinforced Concrete. http://www.ir.juit.ac.in:8080/jspui/handle/123456789/22952 (November 7, 2019).

Möller R, Mild G. 2019. Protection of Moso Bamboo (Phyllostachys pubescens) Materials against Fungal Decay and Discolouration by Treatment with Wood Preservatives. European Journal of Wood and Wood Products 77(1): 139-45.

Morisco. 2006. Teknologi Bambu. Universitas Gadjah Mada Press, Yogyakarta.

Noverma N. 2017. Peranan Bambu dalam Mendukung Pembangunan Wilayah Yang Berkelanjutan. http://digilib.uinsby.ac.id/21674/ (November 7, 2019).

. 2018. Pengurangan Resiko Bencana Melalui Pemanfaatan Bambu. Proceeding in Seminar.Unand.Ac.Id, https://seminar.unand.ac.id/index.php/iabi/pit5iabi2018/paper/ view/177 (November 7, 2019).

Uslinawaty Z, Muin M, Putranto B, Suhasman S. 2019. Optimization of $\mathrm{SC}-\mathrm{CO}_{2}$ Time Conditions and Permethrin Concentration in Laminated Bamboo Production Using Surface Response Methodology. IOP Conference Series: Materials Science and Engineering 593: 012022. 
THIS PAGE INTENTIONALLY LEFT BLANK 